$\begin{array}{llllllllllllllllllllllllllll}\text { I } & \text { N } & \text { T } & \text { E } & \text { R } & \text { N } & \text { A } & \text { T } & \text { I } & \text { O } & \text { N } & \text { A } & \text { L } & & \text { M } & 0 & \text { N } & \text { E } & \text { T } & \text { A } & \text { R } & \text { Y } & & \text { F } & \text { U } & \text { N } & \text { D }\end{array}$

CHRISTINE LAGARDE

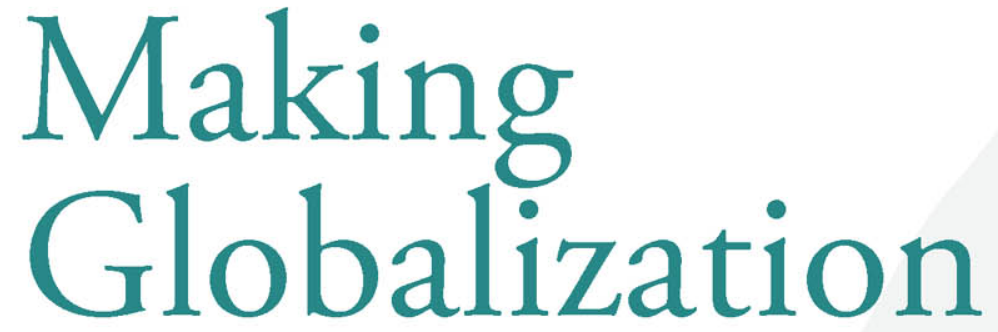

Work for All

Sylvia Ostry Lecture

Toronto • September 13, 2016 
CHRISTINE LAGARDE

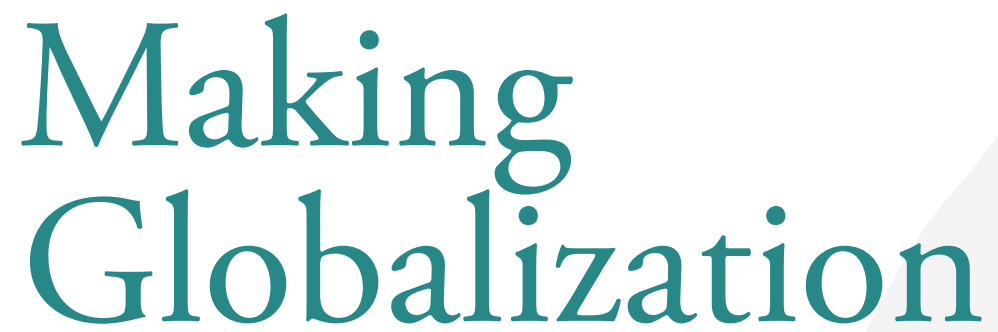

Work for All

\section{Sylvia Ostry Lecture}

Toronto • September 13, 2016 


\title{
Making Globalization Work for All
}

\author{
Sylvia Ostry Lecture
}

\section{CHRISTINE LAGARDE MANAGING DIRECTOR OF THE INTERNATIONAL MONETARY FUND}

\section{Introduction}

I am grateful for the opportunity to deliver a lecture in honor of Sylvia Ostry, the great Canadian economist and policymaker, and above all, the woman pioneer who broke into the closed world of high finance and sherpa-dom that still is largely a man's world.

Dr. Ostry, who is right here in the audience, succeeded by setting the highest standards, not only for economists but for all those who believe that public service is more than just a job.

Sylvia, I would like to start off my remarks today with something important you once said: "We have one asset, and that's people." This message not only reflects Canada's commitment to inclusiveness and openness, but it also captures the essence of policymaking. And as I will argue today, these issues are deeply intertwined.
Openness and international cooperation has always been part of Canada's DNA. Your country has been one of the IMF's strongest partners, with an incredibly positive influence on our institution and other member countries.

The ability of countries to rise above narrow self-interest has brought unprecedented economic progress over the past 70 years.

Conflicts have diminished, diseases have been eradicated, poverty has been reduced, and life expectancy has increased around the world. To paraphrase John Maynard Keynes, one of the IMF's founding fathers: "The brotherhood of man has become more than a slogan."

But progress has not come for everybody at the same pace. There is no doubt that the transformation of our economies has also brought dislocation and hardship.

\section{Conflicts have diminished, diseases have been eradicated, poverty has been reduced, and life expectancy has increased around the world.}


Structural change caused by globalization and technological change has deeply affected some sectors and industries_-while benefitting society as a whole. Concerns over wages, jobs, and future prospects are real and pressing for those who are not well-equipped to thrive in this new world.

This is not the first time we face this challenge. From the days of the bronze age to the industrial revolution and beyond, our ancestors have dealt with the spread of new technologies and the need to adapt. Debates about trade and access to foreign goods are as old as society itself.

But history clearly tells us that closing borders or increasing protectionism is not the way to go. Many countries have tried this route, and just as many have failed. Instead, we need to pursue policies that extend the benefits of openness and integration while alleviating their side effects.

We need to make globalization work for all. That is the focus of my remarks today.

\section{Globalization-the Balance Sheet}

Let me start with the benefits of integrationthe bringing together of trade, migration, capital flows, and technology. This integration has delivered tangible_-real-benefits for most people and most countries.

\section{REAL BENEFITS}

Emerging and developing economies have been the prime beneficiaries of economic openness. According to the World Bank, trade has helped reduce by half the proportion of the global population living in extreme poverty (1990-2010).

China, for instance, saw a phenomenal drop in its extreme poverty rate-from 36 percent at the end of the 1990s to 6 percent in $2011 .^{1}$ Another example is Vietnam, which-in a single generation-moved from being one of the world's poorest nations to middle-income status - which has allowed for increased investments in health and education.

\section{Structural change caused by globalization and technological change has deeply affected some sectors and industries - while benefitting society as a whole.}




\section{History clearly tells us that closing borders or increasing protectionism is not the way to go. Instead, we need to pursue policies that extend the benefits of openness and integration.}

Today, Vietnam can be proud of the fact that it ranks well above most of its richer peers in basic science, math, and reading skills. Its overall score in the latest OECD survey of 15-year olds was higher than that of France, Germany, the United Kingdom, and the United States. ${ }^{2}$

But even in advanced economies, economic integration has lifted living standardsbecause of a more efficient allocation of capital, productivity increases, and lower prices for consumers. Research on the consumer benefits suggests that trade has roughly doubled the real incomes for a typical household. And for the poorest households, trade has raised real incomes by more than 150 percent. $^{3}$

Along with higher incomes, millions of new jobs were created that tend to pay relatively higher wages. In the United States, for instance, workers in export-intensive industries earn a premium perhaps as high as 15 percent over other industries. ${ }^{4}$

In the European Union, more than 30 million jobs - that is, one in every seven-depends on exports to the rest of the world. And in Canada, international trade makes up twothirds of GDP.
Canada is also a prime example of the benefits of migration. By welcoming about a quarter million migrants per year-and by opening their homes and hearts to refugeesCanadians are supporting growth, rejuvenating their workforce, and adding to the richness and diversity of their society.

As the economist and Nobel laureate, Amartya Sen, put it: global economic integration "has enriched the world scientifically and culturally, and benefited many people economically as well." Many people would agree with thatbut it is not the whole story.

\section{REAL SIDE EFFECTS}

The historic events of the early 1990s, when China, India, and the former communist countries entered into the global trading system, had far-reaching effects. The size of the global workforce effectively doubled, putting downward pressure on wages, especially for lower-skilled workers in advanced economies. 
In the United States, competition from lowwage countries has been one of the factors that have contributed to a decline in manufacturing employment, along with a wave of automation. ${ }^{5}$ And this has not been spread evenly across the whole economy, but has been concentrated in some local labor markets that have faced deep, long-lasting effects from overseas competition. ${ }^{6}$

Many have also underestimated the globalization of capital. Between 1980 and 2007, global capital flows increased more than 25-fold, compared with an eight-fold expansion in global trade. This has underpinned investment, especially in emerging economies. But it has also opened the door to financial contagion and concerns about the stability of financial systems.

And lastly, growing inequality in wealth, income, and opportunity in many countries has added to a groundswell of discontent, especially in the industrialized world-a growing sense among some citizens that they "lack control," that the system is somehow against them.
Financial institutions are being seen as unaccountable to society. Tax systems allow multinational companies and wealthy individuals not to pay what many would consider a fair share. Corruption remains endemic. And there is the challenge from uncontrolled migration flows, contributing to economic and cultural anxieties.

These concerns need to be addressed. How can we maintain the benefits from globalization while sharing them more widely? What can governments do?

\section{What Can Governments Do?}

The first order of business is for governments to establish a positive environment for growth. This provides additional income to be distributed, as well as room for policy initiatives.

Unfortunately, growth has been too low for too long: 2016 is set to be the fifth consecutive year with global GDP growth below 3.7 percent, the average for nearly two decades before the 2008 financial crisis.

\section{Growing inequality in wealth, income, and opportunity in many countries has added to a groundswell of discontent, especially in the industrialized world.}


Growth has also been unequal: in major advanced economies, incomes for the top 10 percent increased by 40 percent in the past two decades, while growing only modestly at the bottom. ${ }^{7}$ If we are to build support for open economies and open societies, we have to do better.

How? We know that sound macroeconomic policies and reforms lift productivity and potential growth. We also know that these policies and reforms need to be tailored to achieve the best possible results.

For example, when it comes to support for demand, central banks have done the heavy lifting in recent years. Now fiscal policy needs to play a bigger role in countries that have additional spending headroom. Canada is, in fact, leading the way by stepping up its infrastructure investment and by increasing transfers to families with children.

When it comes to economic reforms, policymakers need to do the right thing in the right sequence - and do it now. Euro Area countries, for example, can lift productivity by accelerating structural reforms-lowering barriers to entry in the services sector, including professional services, and stepping up research and development.

But to maximize the benefits of these structural reforms, they need to be combined with the right fiscal and monetary policies-a three-pronged approach. In the mid-1990s, for example, the Netherlands combined labor tax cuts with major reforms in labor and product markets-resulting in a period of strong growth.
And right now, of course, the Canadian government is following in the same path of taking bold action on fiscal policy and economic reforms.

I have made the case for this strong threepronged policy approach to our membership and to the leaders at the recent G-20 Summit-and I hope that many countries follow Prime Minister Trudeau's global leadership. The more countries adopt it, the greater the mutual benefits for growth.

\section{MORE SUPPORT AND GREATER FAIRNESS}

But how to make growth more inclusive and benefit workers across all economic sectors is a question that does not lend itself to the same clear-cut policy message. It is a challenge of a different order, because it has to do with economic incentives, but also with social, regional, and often ethnic and cultural factors that are hard to overcome- and require country-specific solutions.

Let me speak to the economic policies involved, without having any illusions about the difficulties of the task at hand. The IMF has recommended combinations of the following policy tools to its member countries over the past years:

\section{First—step up direct support for}

lower-skilled workers. This means greater public investment in education, re-training, and facilitating occupational and geographic mobility.

- For example, the German apprenticeship system is often cited as a model that has provided generations of German youth a successful path into skilled work without a college education. 
- Similarly, expanding vocational training partnerships between industry and educational institutions would help retool the labor force and boost employment in countries such as Canada, France, and the United Kingdom.

\section{Second-strengthen social safety nets} by providing appropriate unemployment insurance, health benefits, and portable pensions - and by stepping up tax and income policies.

- The U.S., for instance, could cushion labor market dislocations by increasing the federal minimum wage and expanding the earned income tax credit.

- Another example is the Nordic countries, where workers have only limited job protection, but they benefit from generous unemployment insurance that requires jobseekers to find new positions. This model makes the labor market more flexible - which is good for growth-while safeguarding the interests of workers. ${ }^{8}$

Third-boost economic fairness to rebuild trust and bolster support for reforms.

- This means, for example, addressing the lack of vigorous competition in key areas. Think of major industries_-from banking to pharmaceuticals to social media-where some advanced economies are facing large increases in market concentration. ${ }^{?}$

- Boosting fairness also means clamping down on tax evasion and preventing the artificial shifting of business profits to lowtax locations. The IMF is working on this issue intensively, often in close collaboration with the OECD, the United Nations, and the World Bank.
These measures can help create a positive feedback loop: stronger, more inclusive growth reduces economic inequality and increases support for further reforms and openness.

But as I said earlier, these policies are not sufficient-depending on each country's situation, they need to be accompanied by steps to facilitate equal access to opportunity through education and health care, reduce ethnic and gender discrimination, and foster greater mobility, just to name a few.

\section{Step Up Global Cooperation}

Let me come to my last point.

Perhaps the most important policy insight from the past 70 years is that countries and governments can do a lot to boost economic welfare, but they cannot do it alone.

As Martin Luther King once said, "We are caught in an inescapable network of mutuality, tied in a single garment of destiny. Whatever affects one directly, affects all indirectly.”

\section{REINVIGORATE TRADE}

Nowhere are the issues of economic interdependency greater than in the area of trade.

For two decades before the 2000's, global trade regularly grew by 7 percent, or twice the rate of the world economy. Today, however, trade growth is below that of the global economy—at about 2 percent. ${ }^{10}$ 


\section{Today's generation of leaders and policymakers will be measured by their ability to create a global village on a human scale-a place where people can find a safe and prosperous home for themselves and their children.}

Moreover, there is a growing risk of politicians seeking office by promising to "get tough" with foreign trade partners through punitive tariffs or other restrictions on trade.

I am deeply concerned about this-not only because I was a Minister of Trade, but because trade has been at the heart of the IMF's mandate for more than 70 years.

And for good reason. A stronger trade engine means more competitive industries that have greater incentives for innovation. It means technological innovation gets transmitted in ways that lower prices for consumers and companies.

To illustrate the consumer benefits, one analyst recently compared products listed in the 1971 edition of the Sears-Roebuck catalogue with comparable modern-day items. He found that almost everything in its pages was made in US and that, after adjusting for inflation, products are significantly cheaper today.
For example, a three-speed air conditioner was advertised for $\$ 139.95$, which would come to more than $\$ 820$ adjusted for inflation. Today Frigidaire $^{11}$ offers a model with the same features for $\$ 139.99 .{ }^{12}$

As a result, the average American worker today works only about 17 weeks to live at the annual income level of the average worker in 1915. We have seen similar progress in all countries in recent decades, and this is what trade is about: spreading and sharing economic welfare gains from better technology across the global population. ${ }^{13}$

\section{NEW DEALS}

Against this background, recent news about multilateral trade negotiations have been quite discouraging. But I strongly believe that we can rebuild momentum for trade reforms if the benefits are properly explained, and if we engage in the policies to achieve stronger and more equitable growth that I outlined earlier. 
There are also new 21st-century issues to explore-such as trade in services. This trade is already worth $\$ 5$ trillion a year, or twothirds of global GDP. ${ }^{14}$ However, the barriers to trade in services are extremely high-equivalent to tariffs of some 30 to 50 percent. ${ }^{15}$

One way forward would be to push for so-called "plurilateral" trade agreementsthat is, deals among a limited numbers of like-minded countries that agree to work within the framework of the World Trade Organization. Such deals would be open-on the same terms - to all WTO members.

Similarly, there is room to boost trade in digital products, for example, by establishing freedom of data flows that could help realize the full potential of global e-commerce.

\section{Conclusion}

Some 50 years ago, the Canadian philosopher Marshall McLuhan described how technology had shrunk the world into a "global village".

Today's generation of leaders and policymakers will be measured by their ability to create a global village on a human scale-a place where people can find a safe and prosperous home for themselves and their children.

The IMF - with its analytical and financial resources-will continue to push for and help in this endeavor.

Economic openness and collaboration is in our DNA, too. It is the very reason for which the IMF was founded.

Thank you very much.

\section{ENDNOTES}

1. World Bank figures: World Development Indicators.

2. OECD Program for International Student Assessment: Report: PISA 2012 Results in Focus.

3. Pablo Fagjelbaum and Amit Khandelwal, 2016, Measuring the Unequal Gains from Trade, Quarterly Journal of Economics, 2016.

4. U.S. President's Council of Economic Advisers (CEA): Report: The Economic Benefits of Trade, May 2015.

5. Justin R. Pierce and Peter K. Schott: The Surprisingly Swift Decline of U.S. Manufacturing Employment, NBER Working Paper, December 2012.

6. David Autor, David Dorn, and Gordon Hanson: The China Shock: Learning from Labor Market Adjustment to Large Changes in Trade, NBER Working Paper, February 2016.

7. Countries: Canada, Germany, Italy, United Kingdom, United States. IMF Note: Global Prospects and Policy Challenges, G20 Leaders' Summit, September 4-5, 2016.

8. For more information on the Nordic model: IMF note on Labor Market Policies, IMF paper on Jobs and Growth.

9. Jason Furman: Benefits of Competition and Indicators of Market Power, U.S. President's Council of Economic Advisers Issue Brief, April 2016.

10. IMF, World Economic Outlook database.

11. Frigidaire is the American consumer and commercial home appliances brand subsidiary of European parent company Electrolux.

12. Rob Cox: Cuts like a knife, Reuters, Breaking Views Column.

13. David Autor, 2014, "Why Are There Still So Many Jobs? The History and Future of Workplace Automation," Journal of Economic Perspectives, Vol. 29, No. 3, pp. 3-30.

14. World Trade Organization figure.

15. Lionel Fontagné and others, Estimations of Tariff Equivalents for the Services Sectors, Paper, Centre d'Études Prospectives et d'Informations Internationales (CEPII), December 2011. 


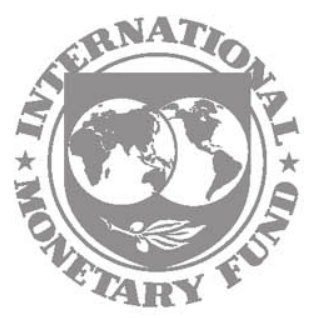

I SBN 978-147553646-1

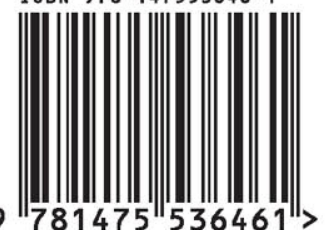

